\title{
Why Insurgent Campaigns Rarely Win the Democratic Presidential Primary in the United States
}

\begin{abstract}
By L. Jan Reid*
The Merriam-Webster dictionary defines insurgent as "one who acts contrary to the policies and decisions of one's own political party." In this paper, an "insurgent presidential campaign" is defined as the campaign of a candidate who did not have the support of the United States of America's (U.S.) Democratic Party establishment. A "populist campaign" is a subset of an insurgent campaign, because although all populist campaigns are insurgent campaigns, not all insurgent campaigns are populist campaigns. This paper defines a "populist campaign" as one that seeks to mobilize an unrepresented segment of the population against an institution or government, usually in defense of the unrepresented. Whether left-wing or right-wing, populist candidates seek to unite the supposedly uncorrupt and unsophis $\neg$ ticated unrepresented against supposedly corrupt dominant elites. Insurgent campaigns have rarely been successful in capturing the Democratic Party presidential nomination in the United States. Only three insurgent campaigns have been successful over the past 50 years: the campaigns of George McGovern in 1972, Jimmy Carter in 1976, and Barack Obama in 2008, all of which were populist campaigns. The paper analyzes U.S. presidential campaigns for the period 19682016; reviews books and academic literature; and makes conclusions concerning the success and failure of insurgent campaigns. Finally, the paper recommends ways in which future insurgent campaigns could be more successful.
\end{abstract}

Keywords: Insurgent Campaigns, Populism, Presidential Campaigns.

\section{Introduction}

This paper analyzes presidential campaigns in the United States' (U.S.) Democratic Party for the period 1968-2016; reviews books and academic literature; and makes conclusions concerning the success and failure of insurgent campaigns.

In order to win the Democratic presidential nomination, a candidate must receive over $50 \%$ of the votes of delegates to the Democratic National Convention. Delegates consist of appointed superdelegates, and delegates chosen in direct primary elections and in state caucuses. In a direct primary, voters cast ballots for delegates who are pledged to vote for a candidate. Direct primaries have become more popular over time. The number of direct primaries has grown from 13 of the 50 U.S. states in 1968 to 38 states in 2016.

Superdelegates are party insiders such as elected politicians and Democratic Party officials. ${ }^{1}$ In 2016, the superdelegates (15\% of the total number of delegates) were composed of:

${ }^{*}$ President, Coast Economic Consulting, USA. 
437 elected members from the Democratic National Committee (DNC) (including the chairs and vice-chairs of each state's Democratic Party)

20 distinguished party leaders, consisting of current and former presidents, current and former vice-presidents, former congressional leaders, and former DNC chairs

191 Democratic members of the United States House of Representatives (including non-voting delegates from Washington, DC and U.S. territories)

47 Democratic members of the United States Senate

21 Democratic governors (including territorial governors) and the Mayor of the District of Columbia).

\section{Hypotheses}

The paper hypothesizes that most Democratic Party insurgent campaigns have been unsuccessful due to lack of money, announcing too late, and inadequate field organization (Field organization includes door-to-door canvassing, contacting voters by telephone, voter registration, and get-out-the-vote campaigns).

\section{Literature Review}

The literature review explored the four subjects discussed below. These subject areas were chosen because, taken together, they help explain much of the success and failure of insurgent campaigns during the period of the study.

The four subjects are:

Causes of Populism

Delegate Selection Rules

Field Organization

Fundraising

\section{Causes of Populism}

There are two theories that seek to explain the rise of populism, which is a subset of insurgent campaigns. These theories are: the economic inequality perspective and the cultural backlash perspective. Inglehart and Norris have explained that according to the economic inequality perspective, "rising economic insecurity and social deprivation among the left-behinds has fueled popular resentment of the political classes" (Inglehart and Norris 2016: 2).

The cultural backlash theory suggests that a surge in votes for populist parties can be explained not as a purely economic phenomenon but in large part as a reaction against progressive cultural change. (Inglehart and Norris 2016: 3)

${ }^{1}$ Of the 259 elected officials who were superdelegates in 2016, populist Sen. Bernie Sanders received the votes of just eight politicians (including himself). 
Inglehart and Norris found that economic inequality and cultural backlash reinforced each other, and that the rise of populist parties constitutes a reaction against a wide range of rapid cultural and economic changes that seem to be eroding the basic values and customs of Western societies.

The work of Inglehart and Norris is focused on right-wing populist parties. Except for the candidacy of Governor George Wallace of Alabama in 1972 and 1976, all of the campaigns in this study were left-wing insurgent campaigns.

The Gini coefficient (also known as the Gini index or Gini ratio) is a measure of statistical dispersion intended to represent the income distribution of a nation's residents and is the most commonly used measure of inequality. It was developed by the Italian statistician and sociologist Corrado Gini and published in his 1912 paper Variability and Mutability (Variabilità e mutabilità). A Gini coefficient of 1 indicates maximum income inequality and a Gini coefficient of 0 indicates no income inequality (Gini 1912).

I was unable to find a significant statistical relationship between support for an insurgent campaign and income inequality as measured by the Gini index. ${ }^{2}$ When the Gini index was regressed against the percent of vote for insurgent campaigns, the paper found that the estimated coefficient was -2.08 with a probability of $17 \%$ ( $83 \%$ significance).

Using a standard $95 \%$ significance level, the regression results indicated no statistically significant relationship between the Gini coefficient and the percent of the vote for insurgent campaigns.

\section{Delegate Selection Rules}

After the 1968 general election, insurgent Democrats engineered a change in the nominating process. Patterson (2016: 17) has pointed out that "State parties were instructed to choose their convention delegates through either a primary election or a caucus open to all registered party voters."

After Senator George McGovern won the democratic nomination but was defeated in a landslide by President Richard Nixon in 1972, the Democratic Party changed its nominating process by establishing a superdelegate system, eliminating winner-take-all primaries, and eliminating the quota system for delegates under age 30 .

\section{Field Organization}

Middleton and Green (2008) studied the effect of MoveOn.org's 2004 efforts on behalf of Democratic presidential candidate John Kerry. They found that voter contacts by MoveOn.org increased voter turnout by $10.5 \%$ among voters contacted by the organization.

Green and Gerber (2000) studied get-out-the-vote efforts and estimated the efficiency of the following methods:

${ }^{2}$ Gini coefficient data for the United States was obtained from the Controller's Office of the State of Nevada. (State of Nevada 2016). 
Canvassing: One additional vote for every 14 people successfully contacted. Phone banks: One additional vote for every 35 people successfully contacted. Literature Drops: One additional vote for every 66 people successfully contacted.

Direct Mail: One additional vote for every 133 people successfully contacted.

\section{Fundraising}

Presidential campaign spending was relatively stable until the 2004 campaign. Figure 1 shows the growth in spending on presidential campaigns over time (Metrocosm.com).

Figure 1. Presidential Campaign Spending (1960-2012)

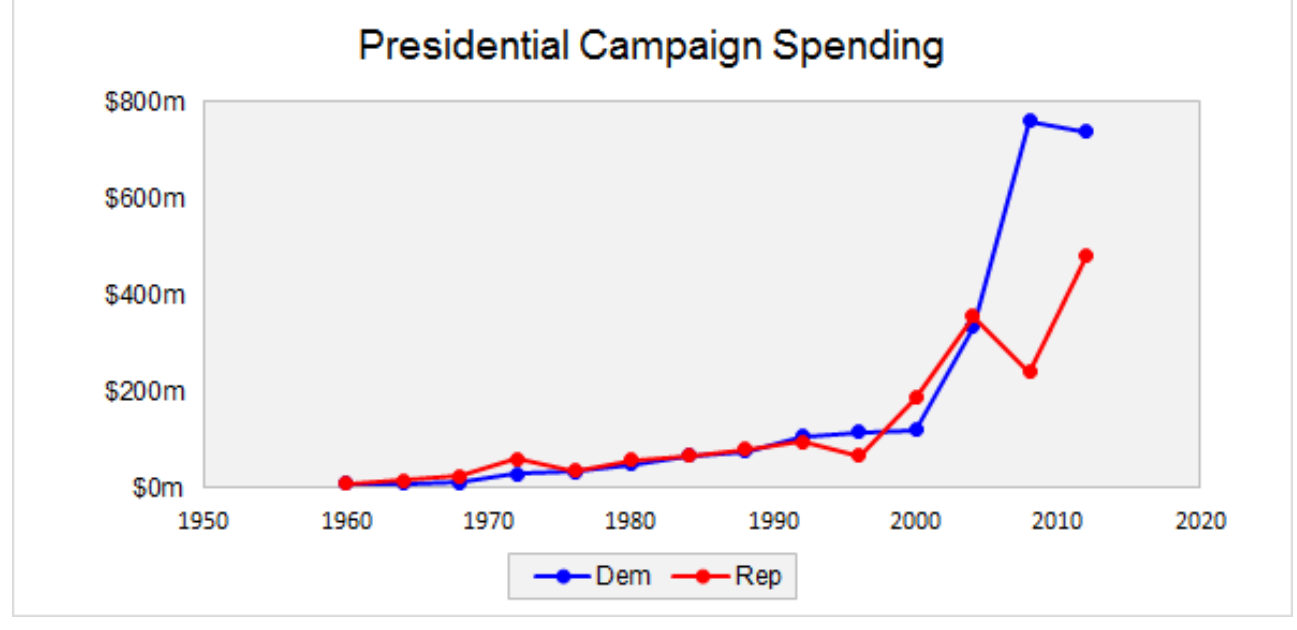

Barack Obama's successful 2008 campaign raised the most money of any insurgent campaign during the period of the study. The second highest was the 2016 campaign of Sen. Bernie Sanders, who raised a total of \$235.4 million. Of this amount, Sanders raised \$215.3 million online from over 8.2 million individual contributors (Weaver 2018: 101).

\section{Electoral History}

Table 1 provides the percentage of the vote for insurgent campaigns in direct primaries from 1968-2016. A graphical representation of these percentages is given in Figure 2. 
Table 1. Insurgent Campaigns from 1968-2016

\begin{tabular}{|c|l|c|l|}
\hline Year & \multicolumn{1}{|c|}{ Candidate(s) } & $\begin{array}{c}\text { Percent of } \\
\text { Vote }\end{array}$ & \multicolumn{1}{|c|}{ Result } \\
\hline 1968 & $\begin{array}{l}\text { Robert Kennedy and } \\
\text { Eugene McCarthy }\end{array}$ & $69.36 \%$ & $\begin{array}{l}\text { Kennedy was assassinated, and } \\
\text { McCarthy finished second at the } \\
\text { Democratic convention. }\end{array}$ \\
\hline 1972 & $\begin{array}{l}\text { George McGovern, } \\
\text { George Wallace, and } \\
\text { Shirley Chisholm }\end{array}$ & $51.51 \%$ & $\begin{array}{l}\text { McGovern won the nomination despite } \\
\text { finishing second to Sen. Hubert } \\
\text { Humphrey in the popular vote. }\end{array}$ \\
\hline 1976 & $\begin{array}{l}\text { Jimmy Carter and George } \\
\text { Wallace }\end{array}$ & $54.43 \%$ & $\begin{array}{l}\text { Carter won the nomination and was } \\
\text { elected President. }\end{array}$ \\
\hline 1980 & Edward "Ted" Kennedy & $37.58 \%$ & President Carter won the nomination. \\
\hline 1984 & $\begin{array}{l}\text { Gary Hart and Jesse } \\
\text { Jackson }\end{array}$ & $58.47 \%$ & $\begin{array}{l}\text { Vice President Walter Mondale won } \\
\text { the nomination. }\end{array}$ \\
\hline 1988 & $\begin{array}{l}\text { Gary Hart and Jesse } \\
\text { Jackson }\end{array}$ & $30.99 \%$ & $\begin{array}{l}\text { Governor Michael Dukakis won the } \\
\text { nomination. }\end{array}$ \\
\hline 1992 & $\begin{array}{l}\text { Jerry Brown and Tom } \\
\text { Harkin }\end{array}$ & $21.59 \%$ & $\begin{array}{l}\text { Governor Bill Clinton won the } \\
\text { nomination. }\end{array}$ \\
\hline 1996 & None & NA & $\begin{array}{l}\text { President Bill Clinton won the } \\
\text { nomination. }\end{array}$ \\
\hline 2000 & None & $\mathbf{4 4 . 6 2 \%}$ & $\begin{array}{l}\text { Vice President Al Gore won the } \\
\text { nomination. }\end{array}$ \\
\hline 2004 & $\begin{array}{l}\text { John Edwards, Howard } \\
\text { Dean, Dennis Kucinich, } \\
\text { and Al Sharpton. }\end{array}$ & $31.09 \%$ & $\begin{array}{l}\text { Senator John Kerry won the } \\
\text { nomination. }\end{array}$ \\
\hline 2008 & Barack Obama & $\begin{array}{l}\text { Despite finishing second in the } \\
\text { popular vote, Barack Obama won the } \\
\text { nomination. }\end{array}$ \\
\hline 2016 & Bernie Sanders & $\begin{array}{l}\text { Senator Hillary Clinton won the } \\
\text { nomination }\end{array}$ \\
\hline Average & $43.84 \%$ & \\
\hline
\end{tabular}

Figure 2. Percent of the Vote of Insurgent Campaigns (1968-2016)

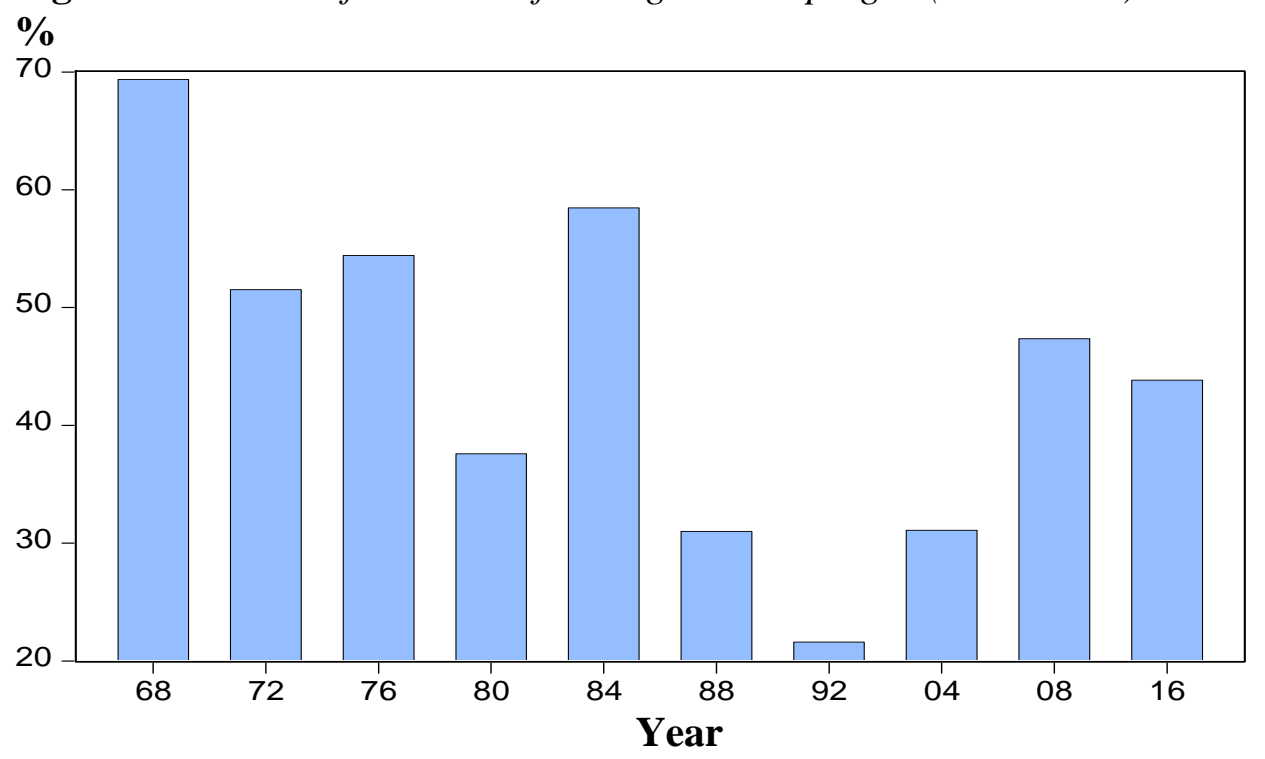




\section{Campaign}

In 1968, Democratic President Lyndon Johnson was running for re-election in the middle of the Vietnam War. He was challenged by the insurgent campaign of Sen. Eugene McCarthy in the New Hampshire primary, and later by Sen. Robert Kennedy.

Despite the growing opposition to Johnson's policies in Vietnam, no prominent Democratic politician was prepared to run against a sitting president of the Democratic party. Antiwar activists formed a "Dump Johnson" movement and initially approached Senator Robert F. Kennedy of New York. They then appealed to Senator Frank Church of Idaho, Senator George McGovern of South Dakota, and Senator Eugene McCarthy of Minnesota. Efforts to draft McCarthy were successful, and McCarthy ran as an antiwar candidate in the New Hampshire primary (Herzog 1969).

On March 12, McCarthy won $42 \%$ of the primary vote to Johnson's 49\%. On March 16, Sen. Edward "Ted" Kennedy announced for president and renounced his earlier support for Johnson. On March 31, Johnson announced that he would not run for re-election.

From that point on, Vice President Hubert Humphrey became the favored candidate of the Democratic establishment. He had the support of President Johnson and was the favorite to win the nomination. Kennedy realized that he would not be able to win enough delegates in primaries to obtain the nomination but hoped that he would be able to sway enough delegates at the convention to deny Humphrey a first-ballot nomination.

Robert Kennedy was assassinated on June 5, 1968. At the time of his death, the committed delegate totals were Humphrey 561, Kennedy 393, and McCarthy 258. Of the remaining 1,385 delegates appointed by politicians or chosen by caucuses, Humphrey received 1,198 (86.5\%) of the outstanding delegate votes and easily won the nomination (Holland 1996).

\section{Campaign}

Initially, the Democratic Party establishment had supported Sen. Ed Muskie, who was the vice-presidential nominee in 1968. After Muskie withdrew from the race on April 28, 1972, Humphrey became the establishment candidate. Humphrey's primary opposition came from the insurgent campaigns of McGovern and Wallace. Wallace was best known for his segregationist history and for his flamboyant opposition to the school busing of children in order to achieve racial balance in public schools.

Wallace ran what was later described as a "rock star" campaign in which he organized large pro-Wallace rallies throughout the country in the hope of winning primary elections. His efforts were successful; Wallace won several primaries outside of his southern base.

Wallace was shot on May 15, 1972 and confined to a wheelchair, thereby effectively ending his campaign. On the following day primaries were held in Michigan and Maryland, both of which Wallace won. A Gallup poll of Democratic 
Party voters conducted from May 1, 1972 to May 15, 1972 found that Wallace and Humphrey were tied at 26\%, followed by McGovern at 25\% (Our Campaigns 2016).

The McGovern campaign had strong field organization but weak fundraising, raising only \$5.45 million during the primaries (Hart 1973). McGovern's field organization was unique in that it encouraged local campaigns and provided them with literature far in advance of their state primaries.

McGovern, who finished second in the popular vote, won seven out of 22 direct primaries, compared to five for Wallace and four for Humphrey. McGovern won the nomination because he had a better understanding of the delegate selection rules, was able to win the majority of caucus states, and because he was able to win "winner-take-all" primaries.

In 1972, 22 states held direct primaries, many with different delegate allocation rules. Seven states held winner-take-all primaries in which the candidate who got the most votes received all of the delegates for that state. Winner-take-all primaries were held in California, Massachusetts, New York, Oregon, Rhode Island, South Dakota, and Tennessee. Out of 3,014 convention delegates, 725 (24\%) were chosen in these seven states. McGovern received the votes of 676 (93\%) of the 725 delegates chosen in these seven primaries. Wallace carried Tennessee and received 49 delegate votes (Skelley 2016).

In 1972, both the Wallace and the McGovern campaigns had two important characteristics: a large group of committed supporters, and a shortage of money. The McGovern campaign was the first to recognize the importance of caucus states. Caucus states were easier for insurgent candidates to win because caucus attendees tended to be the most committed activists. Additionally, caucus-state campaigns were much less expensive than direct primaries. As a result, McGovern won nine out of 13 of the caucus states in which delegates were committed to a candidate. In 18 caucuses, all of the elected delegates were uncommitted.

\section{Campaign}

The Democratic Party establishment was not able to coalesce around a single candidate in 1976. The 1976 campaign was decided by superior strategy and was not strongly affected by fundraising or field organization.

The Democratic Party eliminated winner-take-all primaries in 1976 and apportioned delegates by the share of the vote for each candidate who received over $20 \%$ of the vote. Unfortunately, most candidates did not understand the new system.

Most of the Democratic candidates failed to realize the significance of the increased number of primaries, or the importance of creating momentum by winning the earliest contests. The one candidate who did see the opportunities in the new nominating system was Jimmy Carter, a former state senator and Governor of Georgia. Carter won the nomination because he understood the delegate selection rules and because he devised a strategy to exploit those rules.

Carter's strategy was to run in all of the primaries and caucuses, beginning with the Iowa caucus, thus building momentum by winning "somewhere" each 
time primary elections were held. Carter finished second in the Iowa caucuses and won the New Hampshire primary on February 24, proving that a Southerner could win in the North. He defeated George Wallace in the North Carolina primary March 23, thus eliminating his main rival in the South. He defeated Sen. Henry Jackson in Pennsylvania on April 27, and Jackson quit the race. On April 6, Carter won the Wisconsin primary and eliminated Rep. Morris "Mo" Udall as a serious contender.

\section{Campaign}

Sen. Ted Kennedy was the insurgent candidate in 1980 when he ran against incumbent President Jimmy Carter. Kennedy received only $37 \%$ of the vote and was easily defeated by Carter. Although Kennedy had a strong fundraising base, he lost because he ran against an incumbent, he failed to build a strong field organization, and he announced too late. He announced on November 7, 1979, less than seven months before the last primary on June 3, 1980 (4president.org 2011).

\section{Campaign}

In 1984, former vice president Walter Mondale was opposed by the insurgent campaigns of Sen. Gary Hart and Rev. Jesse Jackson. Jackson was the first viable African-American candidate for the Democratic Party nomination, receiving $18.1 \%$ of the votes cast. Hart won 17 primaries, Mondale won eight, and Jackson two. In theory, the insurgent campaigns were unsuccessful because they took votes away from one another. In total, insurgent campaigns received more votes than Mondale in ten primaries won by Mondale.

\section{Campaign}

In 1988, Gov. Michael Dukakis of Massachusetts was supported by the Democratic establishment. As in 1984, the establishment candidate was opposed by Gary Hart and Jesse Jackson. Hart withdrew from the race on March 12, 1988, leaving Jackson as the only serious opposition to the Dukakis candidacy.

Although Jackson had a good field organization in direct primaries, his campaign suffered from lack of money. Jackson lost the nomination because he announced too late, he failed to win caucus states, and he had inadequate funds (see Tables 2-4). In contrast to previous insurgent campaigns, Jackson won a plurality of delegates in only two out of eleven caucus states (Delaware and Michigan) (Our Campaigns 2016).

\section{Campaign}

In 1992, establishment candidate Bill Clinton was opposed by the insurgent campaigns of then-former governor of California Edmund Gerald "Jerry" Brown Jr. and Sen. Tom Harkin of Iowa. The latter two were the weakest showings of any of the insurgent campaigns in the study, and Clinton easily won the nomination. 
The insurgent campaigns had inadequate funds, and poor or nonexistent field organization, as measured by their performance in caucus states.

Of the 15 caucus states, Clinton won ten, Brown won two, and Harkin won three. Out of $\$ 92.05$ million raised in the 1992 primary, Clinton raised $\$ 44.96$ million, Brown \$11.31 million, and Harkin \$6.03 million. In percentage terms, Brown raised $12.29 \%$ of the money and received $20.2 \%$ of the vote; while Harkin raised $6.55 \%$ of the money and received $1.4 \%$ of the vote.

\section{Campaign}

In 2004, establishment candidate Sen. John Kerry was opposed by the insurgent campaigns of Sen. John Edwards of North Carolina, former governor Howard Dean of Vermont, Rep. Dennis Kucinich of Ohio, and Rev. Al Sharpton. The most notable of the four campaigns was conducted by Edwards, who received $19.4 \%$ of the vote. The four campaigns raised $\$ 100$ million out of total fundraising of $\$ 420$ million. Thus, they raised $24.3 \%$ of the total funds and received $31.1 \%$ of the vote. As with past insurgent campaigns, their loss can be attributed to lack of money and poor field organization.

Their poor field organization is best illustrated by their performance in caucuses. Edwards won the caucus in his home state of North Carolina, but Kerry won the other 18 caucuses (Leip 2012).

\section{Campaign}

Figure 3. Superdelegate Support in the 2008 Campaign

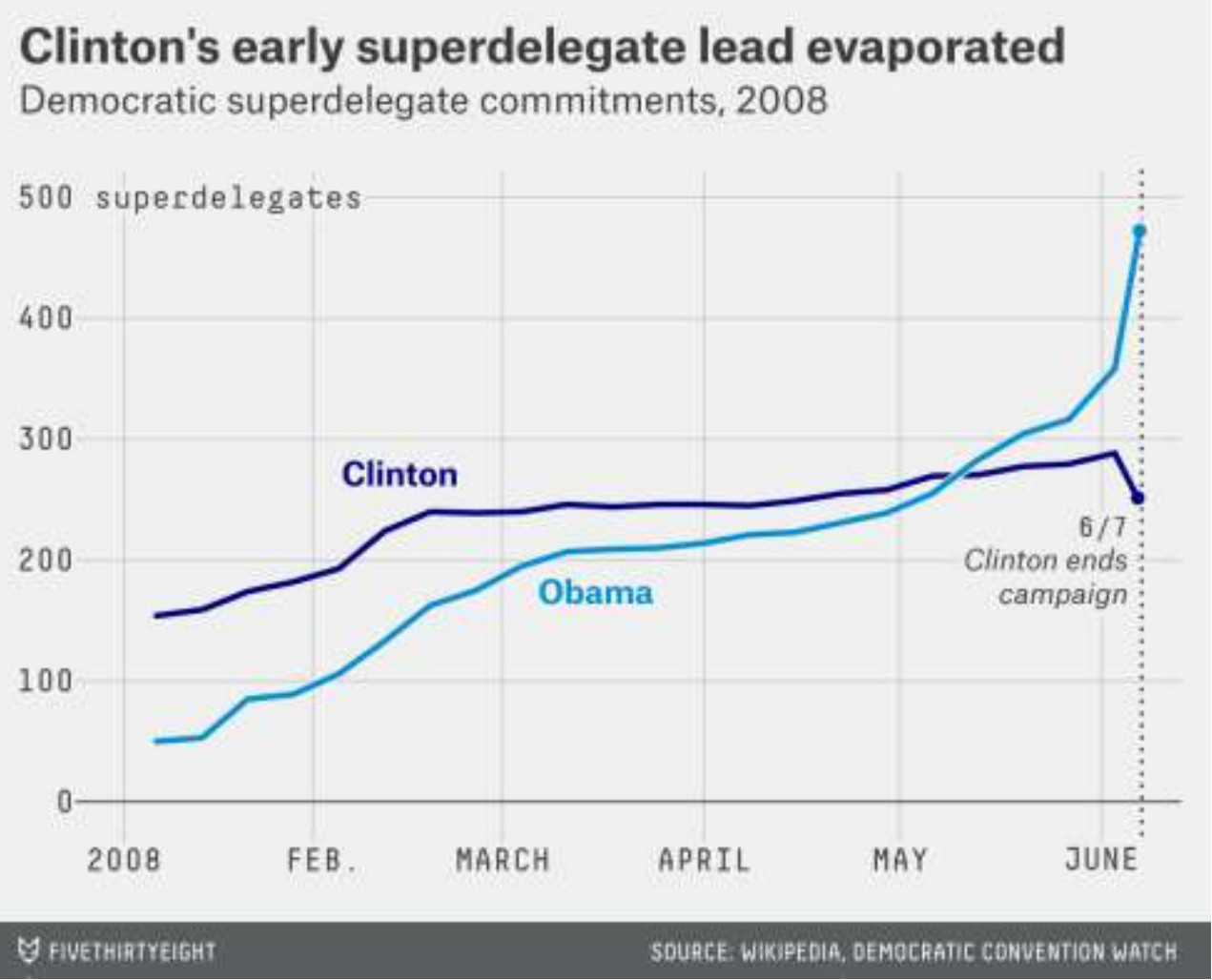


Hillary Clinton, who was opposed by Sen. Barack Obama, was initially supported by the Democratic Party establishment. In February 2008, Clinton had a lead among superdelegates of approximate 100 delegate votes. By May 2008, her lead among superdelegates had evaporated as the establishment switched their support from Clinton to Obama. Figure 3 shows the level of superdelegate support for the two candidates over time (Silver 2016).

In the direct primaries, Obama received $47.4 \%$ of the vote; and Clinton received $48.0 \%$. Obama had superior field organization, as evidenced by his victories in seven out of eight caucuses. Obama was also able to raise more money than Clinton. Obama raised \$339.3 million; and Clinton raised \$233 million.

Obama won the nomination because his campaign was well funded and had a superior field organization (Obama's campaign raised more money than any previous insurgent campaign).

\section{Campaign}

In 2016, Hillary Clinton was again the establishment candidate, and was opposed by Sen. Bernie Sanders of Vermont. The Sanders campaign received $43.84 \%$ of the vote, which was the second-best showing by a single insurgent campaign in the Democratic primary in the period of the study. The success of the Sanders campaign was due to a combination of good field organization and the excellent use of social media, including online fundraising expertise. Sanders had over 8 million followers on three social-media platforms: Facebook, Twitter, and Instagram (Weaver 2018: 102).

As of June 30, 2016, Sanders had raised $\$ 235.4$ million, or $45.4 \%$ of the funds raised by all candidates in the 2016 Democratic primary. (Federal Election Commission 2016) Clinton won 55.2\% of the popular vote and defeated Sanders at the Democratic convention by a margin of 2,842 to 1,665 , in part due to support from superdelegates. In summary, Sanders raised $45.2 \%$ of the money, received $43.8 \%$ of the votes cast, but only $36.9 \%$ of the votes of delegates.

Although Sanders raised more money than any other insurgent campaign except Obama in 2008, the paper estimates that Sanders may have won the nomination if he had been able to raise still more money and used that money in a more efficient way. Sanders received $0.96 \%$ of the vote for every percent of total Democratic Party primary fundraising. In order to win a plurality $(49.5 \%)$ of the popular vote, Sanders would have needed to raise $47.6 \%$ of total Democratic primary fundraising, or approximately $\$ 265.9$ million. Thus, Sanders would have needed to raise an additional $\$ 30.5$ million, which would be an increase of almost $13 \%(265.9 / 235.4=1.1295)$.

Because a political campaign cannot raise an infinite amount of money, the effectiveness of the money raised depends upon how that money is spent. If more money is spent on rallies or television advertisement, less money will be spent on field organization. Like the Wallace campaigns in 1972 and 1976, the Sanders campaign focused on arranging large public rallies featuring the candidate. These rallies helped the Sanders campaign reach voters and increase turnout, but they resulted in less importance being placed on field organization. 
Sanders lost the nomination because of a shortage of money and inadequate field organization. Sanders won 12 out of 18 caucuses, which was the third best showing of the insurgent campaigns in the study. (Andrews et al. 2016).

On April 27, 2016, the Sanders campaign laid off over 40\% (225 out of 525) of their field organizers (Freeman et al. 2016). Before the layoffs, Sanders had won 17 out of 42 caucuses and primaries compared to only 5 out of 17 caucuses and primaries after the layoffs. The layoffs also may have had a negative effect on the Sanders campaign's polling numbers as reported by RealClear Politics.

On April 24, 2016, USA Today/Suffolk found that Sanders trailed Clinton by a margin of $45 \%$ to $50 \%$ nationally. On June 5, 2018, IBD/TIPP found that Sanders trailed Clinton by $37 \%$ to $51 \%$; a decline of nine points in just 42 days (RealClear Politics 2016).

The effectiveness of an individual voter contact depends upon how personal that contact is. For this reason, door-to-door canvassing is more effective than a telephone call, although telephone calls can reach more voters per hour.

According to California politician Phil Baldwin, "the Sanders campaign prioritized phone calls rather than door to door campaigning." The Sanders campaign identified undecided voters by phone, whom they then contacted in their door-to-door campaign. In some precincts, this resulted in as few as five households being contacted in person.

\section{Analysis of Hypotheses}

The paper hypothesized that most Democratic Party insurgent campaigns have been unsuccessful due to announcing too late, lack of money, and inadequate field organization. The paper provides an analysis of some of these hypotheses below. The paper does not provide regression analysis for these three factors because of a lack of observations.

\section{Announcing too Late}

With the exception of the campaigns of Robert Kennedy and George Wallace, insurgent campaigns are typically not as well known as their establishment opposition. They also initially have less financial resources, which means that they are not able to immediately build their candidacy's name recognition via paid media. Insurgent campaigns must build a constituency slowly through grassroots, person-to-person campaigning. Thus, an insurgent campaign ought to benefit from a longer campaign in which it announces earlier.

The paper compares the campaigns of the leading insurgent during each election to the number of days between the candidate's announcement and the last primary of that campaign year. The results show that of the four candidates with the highest number of campaign days, three (McGovern in 1972, Carter in 1976, and Obama in 2008) won the democratic nomination. The 1984 Hart campaign had the third-highest number of campaign days, but it did not win the nomination. As mentioned previously, there were two insurgent campaigns (Gary Hart and 
Jesse Jackson) in 1984 that competed for the same votes. In part, the Hart campaign was unsuccessful because of the presence of Jackson in the race. The latter two insurgent campaigns received more votes in 1984 than did Mondale in ten primaries won by Mondale. The results are given in Table 2 below.

Table 2. Insurgent Campaigns Performance and Number of Campaign Days (1968-2016)

\begin{tabular}{|l|c|c|}
\hline Candidate & $\begin{array}{c}\text { Campaign } \\
\text { Days }\end{array}$ & Percent of Vote \\
\hline Eugene McCarthy (1968) & 194 & $38.7 \%$ \\
\hline George McGovern (1972) & 519 & $25.3 \%$ \\
\hline Jimmy Carter (1976) & 544 & $40.2 \%$ \\
\hline Ted Kennedy (1980) & 179 & $37.6 \%$ \\
\hline Gary Hart (1984) & 481 & $35.9 \%$ \\
\hline Jesse Jackson (1988) & 248 & $29.4 \%$ \\
\hline Jerry Brown (1992) & 232 & $20.2 \%$ \\
\hline John Edwards (2004) & 266 & $19.4 \%$ \\
\hline Barack Obama (2008) & 479 & $47.4 \%$ \\
\hline Bernie Sanders (2016) & 411 & $43.8 \%$ \\
\hline Average & $\mathbf{3 5 5 . 3}$ & $\mathbf{3 3 . 8 \%}$ \\
\hline
\end{tabular}

\section{Fundraising Deficiencies}

Except for the 2008 Obama campaign, insurgent campaigns have raised far less money than have establishment campaigns. The paper compares the percentage of money raised by insurgent campaigns to the percent of the vote that they received in direct primaries.

In the 2016 primary campaign, Sanders raised \$235.4 million out of a total of $\$ 510.2$ million $(45.43 \%$ ) raised by all candidates, and received $43.84 \%$ of the vote for a ratio of 0.96 . In other words, for every percent of funds raised by Sanders, he received $0.96 \%$ of the votes cast in direct primaries. The results are given in Table 3 below.

Table 3. Insurgent Campaigns Performance and Percent of Money Raised (19722016)

\begin{tabular}{|l|c|c|c|}
\hline Candidate & $\begin{array}{c}\text { Percent of } \\
\text { Money }\end{array}$ & Percent of Vote & Ratio \\
\hline George McGovern (1972) & $26.4 \%$ & $25.3 \%$ & 0.96 \\
\hline Jimmy Carter (1976) & $32.6 \%$ & $40.2 \%$ & 1.23 \\
\hline Ted Kennedy (1980) & $39.9 \%$ & $37.6 \%$ & 0.94 \\
\hline Gary Hart (1984) & $17.6 \%$ & $35.9 \%$ & 2.04 \\
\hline Jesse Jackson (1988) & $22.1 \%$ & $29.4 \%$ & 1.33 \\
\hline Jerry Brown (1992) & $12.3 \%$ & $20.2 \%$ & 1.64 \\
\hline John Edwards (2004) & $7.3 \%$ & $19.4 \%$ & 2.66 \\
\hline Barack Obama (2008) & $50.5 \%$ & $47.4 \%$ & 0.94 \\
\hline Bernie Sanders (2016) & $45.4 \%$ & $43.8 \%$ & 0.96 \\
\hline Average & $\mathbf{3 0 . 1 0 \%}$ & $\mathbf{3 3 . 8 \%}$ & $\mathbf{1 . 3 6}$ \\
\hline
\end{tabular}


The paper found that two of the three successful insurgent campaigns were won by the candidates (Carter in 1976 and Obama in 2008) who raised the most money relative to their competitors.

\section{Field Organization}

The paper used the performance of insurgent campaigns in caucus states as a proxy for the quality of the campaign's field organization. Caucus states should be easier for insurgent candidates to win because caucus attendees tend to be the most committed activists. Additionally, state caucus campaigns are much less expensive than direct primaries.

Since caucus attendees tend to be activists who are aware of the positions of the candidates, it is often not necessary to spend money on media advertising directed toward them. Field organization is more important in caucus states than in direct primaries, because the process of electing delegates and lobbying uncommitted delegates is a very labor-intensive activity.

Using performance in caucus states as a proxy for field organization quality, the paper found that two of the three successful insurgent campaigns were won by the candidates (McGovern in 1972 and Obama in 2008) with the strongest field organizations. The results are given in Table 4 below.

Table 4. Insurgent Campaigns Performance in Caucus States (1972-2016)

\begin{tabular}{|l|c|c|}
\hline Candidate(s) & $\begin{array}{c}\text { Caucus States } \\
\text { Won }\end{array}$ & $\begin{array}{c}\text { Percent of States } \\
\text { Won }\end{array}$ \\
\hline George McGovern (1972) & $9 / 13$ & $69.23 \%$ \\
\hline Jimmy Carter and George Wallace (1976) & $3 / 21$ & $14.29 \%$ \\
\hline Ted Kennedy (1980) & $1 / 14$ & $7.14 \%$ \\
\hline Gary Hart and Jesse Jackson (1984) & $11 / 26$ & $42.31 \%$ \\
\hline Jesse Jackson (1988) & $2 / 11$ & $18.18 \%$ \\
\hline Jerry Brown and Tom Harkin (1992) & $5 / 15$ & $33.33 \%$ \\
\hline John Edwards (2004) & $1 / 17$ & $5.88 \%$ \\
\hline Barack Obama (2008) & $14 / 17$ & $82.35 \%$ \\
\hline Bernie Sanders (2016) & $12 / 18$ & $66.67 \%$ \\
\hline Average & & $\mathbf{3 7 . 7 1 \%}$ \\
\hline
\end{tabular}

\section{Analysis of Results}

The paper hypothesizes that most United States Democratic Party insurgent campaigns have been unsuccessful due to announcing too late, lack of money, and inadequate field organization. The paper provides evidence to suggest that most insurgent campaigns are unsuccessful because of weaknesses in one or more of those three areas. For example, the 2016 Sanders campaign was fifth in the number of campaign days (Table 2), third in fundraising relative to its competitors (Table 3), and third in field organization (Table 4) as measured by caucus-state performance. 
With the exception of the 1968 antiwar campaigns of Eugene McCarthy and Robert Kennedy, insurgent campaigns have not had the support of a majority of voters in Democratic Party primaries. In order for an insurgent campaign to be successful, there must be one strong insurgent candidate running against multiple centrist candidates. This was not true in 1984, when there were two strong insurgent candidates (Hart and Jackson) running against a single establishment candidate (Mondale). As a result, Mondale won the Democratic Party primary nomination, even though Hart and Jackson combined had more votes than Mondale in ten primaries won by Mondale.

To be successful in future U.S. Democratic Party nomination contests, an insurgent campaign must announce early, have adequate funds, build a strong field organization, and develop a strong social-media presence similar to that of Sen. Bernie Sanders' 2016 campaign.

\section{Conclusion}

This paper analyzes presidential campaigns in the United States of America's (U.S.) Democratic Party for the period 1968-2016; reviews books and academic literature; and makes conclusions concerning the success and failure of insurgent campaigns.

The paper hypothesized that most insurgent campaigns have been unsuccessful due to announcing too late, lack of money, and inadequate field organization. The paper provides evidence to suggest that most insurgent campaigns are unsuccessful because of weaknesses in one or more of those three areas. For example, the 2016 Sanders campaign was fifth in the number of campaign days (Table 2), third in fundraising relative to their competitors (Table 3 ), and third in field organization (Table 4) as measured by caucus-state performance.

Finally, the paper recommends that insurgent campaigns should announce early, have adequate funds, build a strong field organization, and develop a strong social-media presence similar to the 2016 campaign of Senator Bernie Sanders.

\section{Acknowledgments}

Thanks to Dr. Katarzyna Romańczyk, Ron Knecht (J.D.), and Phil Baldwin (B.A.) for helpful comments and suggestions, and to Gina L. Serman Reid (B.S.), manuscript editor. 


\section{References}

4president.org (2011) Ted Kennedy 1980 Presidential Campaign Announcement Speech. Retrieved from https://bit.ly/2ADzoym. [Accessed 22 May 2018].

Andrews A, Bennett K, Parlipiano (2016) 2016 Delegate Count and Primary Results. New York Times, July 5, 2016. Retrieved from https://nyti.ms/2kF7I4H. [Accessed 23 May 2018].

Federal Election Commission (2016) Presidential Campaign Finance Summaries, presreceipts_2016_m7.xls. Retrieved from https://bit.ly/2ABJ10q. [Accessed 10 May 2018].

Freeman D, Jansing C, Dann C (2016) Sanders to Lay Off Staff After Tuesday Primary Losses. NBC News. Retrieved from https://nbcnews.to/2CRis98. [Accessed 10 May 2018].

Gini C (1912) Variabilità e mutabilità [Variability and Mutability]. Cuppini C, Bologna, Italy. Reprinted in Memorie di metodologica statistica, (Ed. Pizetti E, Salvemini T). Rome: Libreria Eredi Virgilio Veschi (1955).

Green D, Gerber A (2000) Get Out the Vote. Washington D.C.: Brookings Institute Press.

Hart G (1973) Right from the Start. New York: Quadrangle.

Herzog A (1969) McCarthy for President. New York: The Viking Press.

Holland K (1996) All the Votes . . . Really. CNN.com. Retrieved from https://cnn.it/2OXkOdX. [Accessed 21 May 2018].

Inglehart R, Norris P (2016) Trump, Brexit, and the Rise of Populism: Economic HaveNots and Cultural Backlash. Harvard Kennedy School, Faculty Research Working Paper Series, August 2016. HKS Working Paper No. RWP16-026. Retrieved from https://bit.ly/2SzypGh. [Accessed 25 April 2018].

Leip D (2012) Dave Leip's Atlas of U.S. Presidential Elections. Retrieved from https://bit. ly/2CTrPFu. [Accessed 22 May 2018].

Metrocosm.com (2015) Retrieved from https://bit.ly/2DeI0Or. [Accessed 20 May 2018]

Middleton J, Green D (2008) Do Community-Based Voter Mobilization Campaigns Work Even in Battleground States? Evaluating the Effectiveness of MoveOn's 2004 Outreach Campaign. Quarterly Journal of Political Science 3:63-82.

Our Campaigns (2016) US President $-D$ Primaries. Retrieved from https://bit.ly/2ABUNIl. [Accessed 21 May 2018].

Patterson T (2016) Pre-Primary News Coverage of the 2016 Presidential Race: Trump's Rise, Sanders' Emergence, Clinton's Struggle. HKS Working Paper No. 16-023. Retrieved from SSRN: https://bit.ly/2P1nrLQ. [Accessed 14 May 2018].

RealClear Politics (2016) 2016 Democratic Presidential Nomination. Retrieved from https://bit.ly/2QcqiOF. [Accessed 27 May 2018].

Silver N (2016) Superdelegates Might Not Save Hillary Clinton. FiveThirtyEight.com. Retrieved from https://53eig.ht/2yFm1fK. [Accessed 22 May 2018].

Skelley G (2016) The Modern History of the Democratic Presidential Primary 1972-2008. Sabato's Crystal Ball. University of Virginia Center for Politics. Retrieved from https://bit.ly/2P2Lav6. [Accessed 22 May 2018].

State of Nevada (2016) Controller's Annual Report for Fiscal Year 2017, background material. Retrieved from https://bit.ly/2PE877v. [Accessed 14 May 2018].

Weaver J (2018) How Bernie Won. Thomas Dunne Books: New York: St. Martin's Press. 
